\title{
The miracles of St Thomas of Hereford
}

\author{
J H ROSS, MERYL JANCEY
}

At about 9 am on 18 September 1305 Thomas, aged 14, was crossing the Summergill brook near New Radnor (now in Powys) to gather wild apples for sauce making when he noticed a bundle of red clothes in the water. At first he thought that they had been left there by the washerwoman but soon realised that he had found the body of William De Lorimer, aged 2 $1 / 2$, from Donnington (now Downton) farm, which lay "the distance of an arrow's flight" from the stream. He took the boy out of the water and shouted for help. The occupants of the farm came running out, moved the body to a dry area, and were soon praying to Thomas Cantilupe, the Bishop of Hereford who had died 22 years earlier, to revive the child. They "measured" him (determined his height with the intention of lighting a candle or taper of that length at the Bishop's tomb). While they were busy with Ave Marias and Paternosters a certain Hugh de Adforton left the crowd, opened the boy's mouth, and, separating the teeth with a stick, turned him upside down. Water poured out but he did not obviously show signs of life.

William was taken into the farmhouse, where a fire was lit to warm him "first on one side and then on the other." During the afternoon Hugh de Adforton examined him again. When he put a finger in the child's mouth he was bitten and realised that recovery was occurring. There was steady improvement although "he remained a strange colour for some time."1

\section{Thomas Cantilupe and the Vatican records}

How do we know so much about a resuscitation which took place nearly 700 years ago? This case history is a summary of the descriptions by several witnesses to one of the many miracles ascribed to the relics of Thomas Cantilupe, Bishop of Hereford, who died in 1282 and was canonised in 1320 . Accounts of the miracles were related by the witnesses, in 1307 , to three commissioners appointed by Pope Clement $\mathrm{V}$ to report on the deeds and reputation of Thomas. They heard not only about the miracles which occurred after his death but also about the intimate details and saintliness of his life, making records which were sent to the papal court for consideration. These records are preserved in the Vatican beautifully written in mediaeval Latin, and, from microfilm copies, we have been able to learn much about the daily life in rural England six centuries ago, the medical problems of the time, and the framework of thought which could include miraculous cures as frequent events.

Exact details of the miracles are sometimes difficult to determine and there is wearisome repetition in some of the accounts together with occasional extravagant descriptions so that the evidence has to be approached with caution. The witnesses may have been inhibited by having to fit their testimonies to a strict pattern, a sort of questionnaire, and they had to bring to memory events of many years before. Interpreters were needed, and in Hereford Franciscan friars fulfilled this task. The commissioners spoke Latin and French, but, whereas clerical witnesses might be familiar with these, many laymen could speak only English or Welsh.

Thomas Cantilupe was born about 1218 in Buckinghamshire into a noble family descended from Norman barons. His father held office in the royal household and an uncle was a distinguished Bishop of Worcester. Thomas was destined for the church from an early age and was educated in Oxford, Paris, and Orleans, making a particular study of civil and canon law. Elected Chancellor of Oxford University in 1261 he soon left academic life when he became bound up with the baronial party associated with Simon de Montfort. Thomas was Chancellor of England for a short time after his party's success at the battle of Lewes but had to leave the country after de Montfort's defeat and death at Evesham. He then studied theology in Paris and in 1266 was restored to the king's favour, returning to England and to a succession of academic and ecclesiastical preferments culminating in election as Bishop of Hereford in 127.5 .

Thomas carried out his duties well and was said to have been devout but austere, generous to the poor, humble and abstemious, and possessed of iron discipline and to have indulged in extreme self neglect. His legal training must have been of great value to him both in connection with many disputes which occurred within the diocese and in his work as an adviser to Edward I. It has been said that he indulged unduly in litigation. A series of confrontations with the Archbishop of Canterbury, John Pecham, led in 1282 to the excommunication of Thomas, who, although in poor health, decided to lay his case before the papal court and made the long journey to Orvieto. He was well received by Pope Martin IV but sadly developed a fever, possibly malaria, and died far from home. His bones were prepared as relics in the customary way, separating them from his flesh by boiling, and were brought back to Hereford for burial in the Lady Chapel of the cathedral. Five years later they were moved to a shrine,in the north transept, and miracles, which had already been associated with them in small numbers, increased enormously, bringing numerous pilgrims to Hereford and great wealth to the cathedral treasury.

Miracles continued in decreasing numbers for 20 years and Richard Swinfield, who had succeeded Thomas as bishop, worked ceaselessly at promoting the cause for Thomas's canonisation, helped by appeals from Kings Edward I and II, the Archbishop of York, and many bishops. Finally, in spite of opposition from his old enemy Archbishop Pecham, formal inquiries were started in 1307 and Pope John XXII issued the Bull of Canonisation in 1320. Poor Richard Swinfield never saw his plans realised, having died three years earlier.

The three commissioners spent five months in London and Hereford in 1307 examining evidence related to Thomas's life and posthumous miracles, having first decided that he had not in fact been excommunicated. There were 470 miracles to be catalogued and one has sympathy with the committee, who by the last day of their inquiry had dealt with only 17 of them in detail. The remaining evidence was submitted in a rush of witnesses and paperwork. ${ }^{2}$

\section{Witnesses and pilgrims}

Our purpose here is to relate a few of the medical histories which we have read in the Vatican records and to attempt diagnoses and explanations. A few comments about "miracles," which were so frequent at shrines in England and on the continent in mediaeval times, are necessary. Why were these so frequent and in what light were they considered 700 years ago? It is doubtful if they were needed to strengthen the faith of churchmen in those days any more than they are now (we do not therefore think that our attempted explanations of these events should cause any offence). The miracles did have a missionary effect, assisting the belief of congregations and attracting many pilgrims to the sites of relics, with many consequent benefits to the local foundations. The shrines offered cures and comforts in cases of misfortune and sickness, and the attendants worked hard knowing that there was competition between the shrines for clientele, for successful cures, and for the rewards. ${ }^{3}$ A E Garvie wrote, "As Christ and the Apostles worked miracles, it was assumed that those who in the Church were distinguished for their sanctity would also work miracles; and there can be little doubt that the wish was often father to the thought."

The records show considerable consistency in the testimonies of some of the witnesses and indicate that many were good observers . .

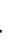

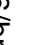
. 
and that those who recorded the cases were intelligent men. The mediaeval lay public possibly had more opportunities for first hand observations of anatomy and pathology than nowadays (although television does, of course, now provide much more detail). Certainly those in holy orders had such opportunities, what with the crowds of the diseased and insane milling around the shrines and the boiling, dismembering, and embalming of bodies for relics, which were apparently part of their duties (some monks might have spent a great deal of time mopping up after miracles ${ }^{3}$ ). It is related that "while Hugh of Lincoln's corpse was being embalmed in the presence of his clergy, his biographer Adam inspected the holy intestines and claimed they were exceptionally clean-a miracle. He querulously added that certain bystanders, who 'made light of the miracle,' replied that the physical condition of the body was due as much to Hugh's dysentery and his pious abstinence as to any miracle."s

a belief in supernatural happenings. If improvement with treatment was so rare and if it did take place in association with prayer then a miracle was assumed to have occurred.

\section{What is a miracle?}

A miracle has been said to be something you wonder at; it must fly in the face of experience and not be merely an exception but "an exception with a point"-possibly a divinely ordained exception. ${ }^{7}$ In our present computerised age, however, when we can rapidly calculate the probability of any event occurring we are able to reduce many exceptions or miracles to happenings with a certain degree of improbability. $^{8}$

Finucane pointed out that, as might be expected, miracles were associated with three types of disease: self limiting, chronic with remissions, and psychogenic. ${ }^{5}$ There were also examples of resuscitation from accidental death due to drowning or head injury, which is not surprising as it may be difficult enough nowadays to diagnose death without complex tests and apparatus. Over half of the $\mathbf{2 0 0 0}$ miracles at the seven major English shrines were related to cures from illnesses with yague general symptoms, or from crippling ailments or from blindness and to escape from disasters such as shipwrecks, captivity, and judicial hanging. Men were associated with miracles more than women, and there was a link of sorts between social classes, sex, some types of miracles, and the shrines of particular saints. ${ }^{5}$ The shrine of Frideswide, patron saint of Oxford city and university, was, for example, visited frequently in the twelfth century by young women with problems related to love and marriage. ${ }^{3}$ Two thirds of her posthumous miracles concerned women.

Visits to the shrines of saints became fewer as the mediaeval period progressed, although pilgrimages to centres associated with Christ and the Virgin Mary increased. Recorded miracles decreased, perhaps because of general dissatisfaction with the church. ${ }^{5}$ The reign of Henry VIII brought disaster to the shrines. Destruction of relics began in 1535 and reached its peak in 1538, with intense "smear campaigns" directed at the saints. Local

Ronald C Finucane, who told this story, has made a careful and very readable study of miracles and pilgrims in mediaeval England with particular reference to nine major cults, including that of Thomas Cantilupe, and his book provides interesting facts and

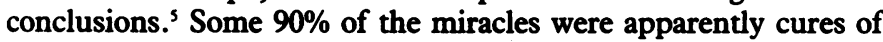
human illnesses and half of them took place in the patients' homes. Miracles rarely occurred immediately but with some delay after the approach to the saint had been made. About $10 \%$ of English pilgrims to shrines had previously sought medical help, and condemnation of the inadequacy of the help from doctors and surgeons was frequent in the records. Mediaeval treatment was no doubt ineffectual, but the observations of the practitioners and their attempts to help might be of a high standard. They are usually thought of as being slavish adherents to the teachings of the great authorities such as Aristotle and Galen, but there is evidence of criticism, some experimentation, and fresh theorising. ${ }^{6}$ The powers of deduction by thinking men and women were probably as good as ours and the disease process and physical disorders which they saw are unlikely to have altered much in 700 years; it was a lack of any detailed scientific framework in which to contemplate human activities and not lack of intelligence which allowed and encouraged faith healers and wise women probably filled the ever present need for alternative medicine, and Finucane believes that the widespread development of hydrotherapy at spas and baths, often at sites of religious importance, was also a substitute for the shrines as places of treatment.

The 17 miracles examined in detail by the commissioners sent to assess Thomas Cantilupe's fitness for canonisation can be classified thus: four resuscitations of children, aged $1 \frac{1}{2}$ to 10 years, from drowning; three cures for paralysis; two recoveries from blindness; two recoveries from head injuries; one recovery from insanity; one restoration of speech; one resolution of a tumour on the neck; one recovery from shipwreck; and two recoveries from hanging.

A few case histories of medical interest have been selected from these 17 and the numerous other records.

\section{Case histories}

\section{Case history 1}

Hugh le Barber appeared before the commissioners in London in July 1307. He was then aged over 70 . He related how he had met Thomas 


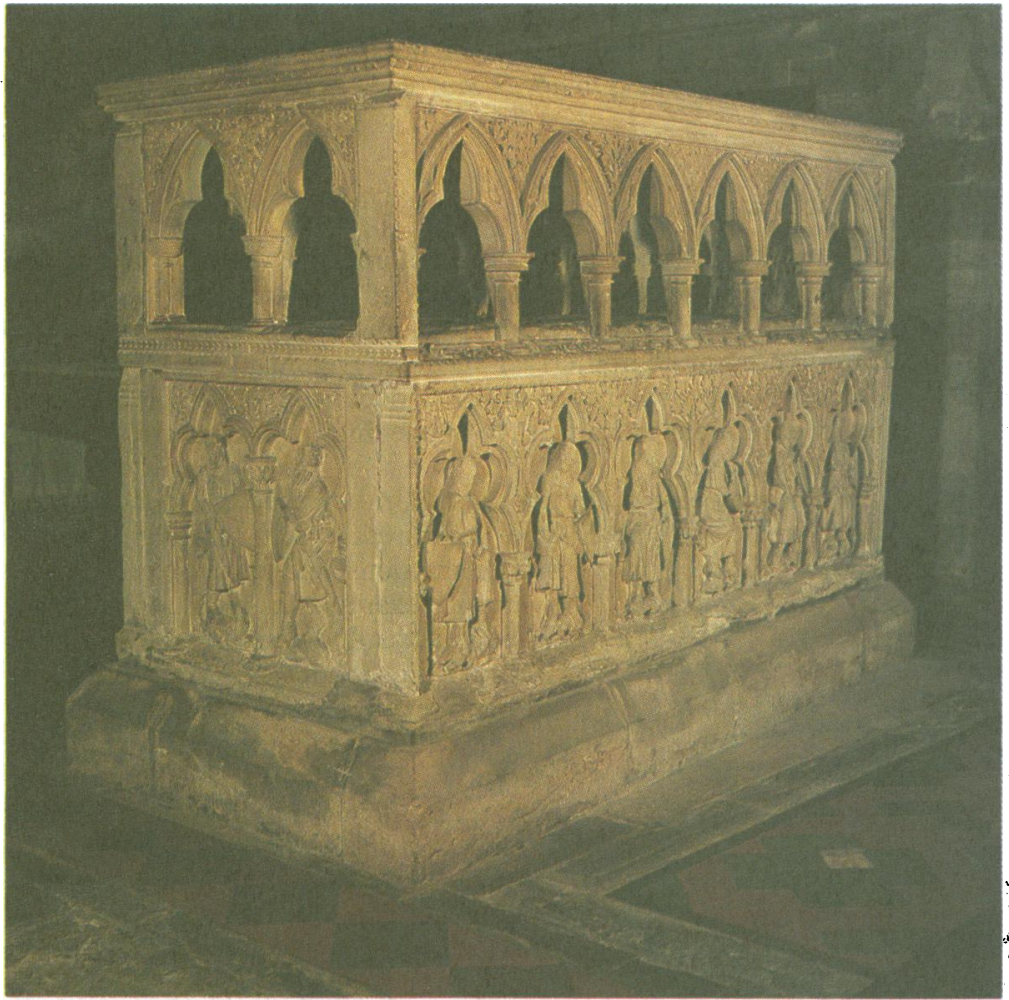

The shrine of St Thomas in the north transept of Hereford Cathedral.

Cantilupe 55 years before in Paris, where he had become his barber and later a general servant in the bishop's household. He gave detailed evidence about Thomas's saintliness, austere practices, and daily routine. Perhaps it is of some medical interest that Hugh said that Thomas's bedding and clothing were always full of lice "ad abhominationem." The source or permanent residence of these parasites was possibly the bishop's hair belt, knotty and spikey, which was alive ("tota repleta") with them.

Hugh told the commissioners about the miracle which had restored his own sight after prayer to Thomas. The date is not given but the miracle had occurred after the death of Thomas 25 years before the inquiry so that Hugh must have been at least $\mathbf{4 0}$ years old. He and his wife were returning home one evening after dining out in London when he had a sharp pain in his head and his right eye felt as though it was filled with ashes. Previously his vision must have been good as he said that he could thread needles. The pain lasted all night, and the next morning, on the way to St Paul's church, he had further similar pain and lost sight in the other eye. Eight days later a surgeon applied a plaster over his eyes but this made him worse and he developed a temporary rash. He remained blind and after an unspecified interval he prayed to and was measured to Thomas. In addition wax models of his eyes were sent to Hambleden, Thomas's birthplace. Two days later his sight was sufficiently recovered for him to see hens walking about near his house. Eight days after the measurement he could move about by himself and could see the Host raised by the priest at the altar, however far away he might be. He was able to play chess within a year and could see the marks on dice. No past history is given except that Hugh mentioned that he had been dissolute in his youth. ${ }^{9}$

Comment-This is an account of the sudden onset of blindness accompanied by pain, becoming bilateral within 24 hours, with șlow but almost complete recovery. It seems likely that Hugh developed iritis with spontaneous remission but it is not possible to determine the aetiology; it would be wrong to assume that his "dissolute" youth was of any importance.

\section{Case history 2}

In 1293 William de Lonsdale was journeying from the north of England to London with his 5 year old daughter Alice. He was on his way to Spain to honour a vow to visit the shrine of St James at Santiago de Compostela. Alice tripped over a hole in the road near Stamford and broke bones in her right foot. William carried her on his shoulders to London, where they crossed London Bridge and lodged in Southwark. She became ill on their first night there, lost power and sensation in her left limbs, and was able to use only her right hand. Life became very difficult and father and daughter were reduced to living in doorways and begging, the child dragging herself along on her thighs. The broken foot became swollen with putrefaction, with a discharge below the ankle, where bones could be seen protruding. Alice told the commissioners in 1307 that she had washed the infected foot in the well of the church of St Clement Danes, there being no other remedy for a beggar such as her, but she was also seen by Master Gilbert, a surgeon, who had put plasters on the foot and told her that the disorder was incurable.

Her father must have heard of the fame of Thomas Cantilupe in London for he prayed to him for a cure, "measuring her and putting a penny on her head." He vowed to visit the tomb in Hereford and to dedicate Alice to St Mary if she was restored to health. He then pushed her to Hereford in a "one wheeled cart" (presumably a wheelbarrow of sorts) and arrived there on the night of Pentecost in 1303. They visited the tomb and on the third night there Alice had a vision in which "a beautiful old man in white clothes, silvery like a lily, with a large ring on a finger and a rich head covering with streamers hanging from it, anointed her body with a milky substance from a little box, touching her from her breasts downwards, including the right foot with its three discharging ulcers and the withered and paralysed left leg." The wounds subsequently dried up and she could walk but only with the aid of a stick as "the sinews of the foot were drawn up and scarred." She was much more active within a week. ${ }^{10}$

Comment-This is an extraordinary story, indicating the great distances which pilgrims were prepared to travel, the sufferings which must have been endured, and a remarkable recovery. Alice must have had a severely infected right foot for 10 years, probably with osteomyelitis, but what was the aetiology of her left sided disorder? It did not apparently affect her right side and a polyneuritis is therefore unlikely. If the sensory loss is to be believed then poliomyelitis is excluded. She is unlikely to have survived an infective endocarditis with a cerebral embolus or mycotic aneurysm. A cerebral abscess with resolution is a rather unlikely possibility. A "paradoxical" embolus from a venous thrombosis in the right leg associated with the infection is another possibility. She was presumably left with some spasticity and contracture of the hemiplegic limbs after the resolution of the infection, which was a remarkable occurrence after 10 years.

\section{Case history 3}

It was well known that a man called John from Hamme (now Holme Lacey) had a tumour on the back of his neck, the size of his fist. He put his head and shoulders through one of the openings in the side of Thomas Cantilupe's tomb and prayed. When he withdrew his head, the tumour had gone: ${ }^{11}$

Comment-The commissioners are reported as being satisfied that this was not a natural event. Many tombs (for example, that of Thomas Becket in Canterbury) had openings so that pilgrims and the sick could put their heads inside among the relics of the saint. Probably the tomb of Thomas Cantilupe was similar and the sceptical can suggest only that Jenkins had a large sebaceous cyst, which somehow ruptured under pressure during passage into or out of the tomb. The present top structure with large arches $(29 \times 32 \mathrm{~cm})$ is probably a later addition and we do not know the dimensions of any previous openings. ${ }^{12}$

\section{Case history 4}

Edith Oldecriste, wife of Robert an ironmonger, recovered in Hereford Cathedral from being "furiosa" (insane) on the Friday before Palm Sunday in 1287. Robert told the commissioners that she had developed the condition one night during the first week of Lent and had woken shouting and cursing and clawing at him with her hands. (Another witness said that she had heard that Edith had had similar trouble previously.) Apparently she had been eating little and "drinking much" before the attack according to her husband; he did not mention alcohol. He had had to restrain her with woollen bindings and engaged two women to watch over her. She was kept at home, remaining delirious without a lucid interval, and her bonds were loosened only when she was fed. Robert, following the advice of neighbours, measured her both to the Holy. Cross of Hereford and to the Holy Cross of Wistanston and prepared two candles. Edith was then carried in a basket with one of the candles to the cathedral, where she remained bound before the altar of the Holy Cross. On the Thursday before Palm Sunday she was moved to the Lady Chapel as a cleric had suggested that she might be helped 
by the relics of Thomas, which had not yet been moved to the north transept. She was returned to the main body of the cathedral in the evening.

On the next day Robert took the other candle and the thread with which he had measured Edith to Wistanston. On the way back he heard the great bells of Hereford ringing and a man came running out to tell him that his wife had been cured through the merits of Bishop Thomas. He found her in sound mind and took her home (in the basket as she was too weak to walk). She remained sane but weak until her death at the time of the feast of St Peter in chains about four months later.

Dom Gilbert, procurator of the cathedral, gave a more dramatic version of the story and said that while he was celebrating mass all the lamps and candles in the cathedral had been suddenly and inexplicably extinguished and there was a noise as of rushing water. The candle at the head of Edith, who was lying bound before the altar; became alight again and then all the others. Edith was freed from her bonds without human help and stood on her feet, sane.

William de Montfort, a precentor of the cathedral, gave a more practical reason for Edith's move to the Lady Chapel saying that her screaming disturbed the clergy and the choir. He was asked if he could say why she might have been "furiosa" and replied that she probably had had a seizure.

A sacristan, who spoke in Welsh, said that he did not think that the cure had been magical or could have been effected by any medical or human agency..$^{13}$

Comment-This miracle is perhaps of more historical than medical interest. The dramatic cure drew widespread attention to the relics of Thomas and their movement by Bishop Swinfield to the north transept a week later, when the cathedral was crowded for Holy Week. It has been suggested that the miracle was in some way publicised for this purpose; certainly miracles immediately proliferated and pilgrims were attracted to Hereford in large numbers.

Most of the witnesses did attribute the cure to Thomas and one of them was rebuked for doing so by an official responsible to Thomas's old enemy Archbishop Pecham, who had delayed the entry of the bones into England and who later wrote "Blessed God! That the Lord performs miracles for excommunicates these days." 14

The accounts of the witnesses to this miracle vary in detail, not surprisingly as they were relating to the commissioners events that had occurred 20 years previously. All do, however, indicate that a mentally deranged woman suddenly became rational again-a not so unusua happening. Alcoholism has been blamed for her condition, ${ }^{15}$ possibly as a result of an article by Canon Bannister, ${ }^{16}$ who was curiously unsympathetic to the miracles of Thomas. He did not, however, consult the original depositions of the witnesses, in which we have found no mention of alcohol. Edith's death, not long after the miracle, does suggest that she may have had a progressive organic disorder, of which the mental disturbance was one manifestation. for the condition to be present from birth and actual deformities of the fingers are unlikely although they might appear misshapen; (b) epidermodysplasia verruciformis. This disorder, which is accompanied by an immune defect, may develop in early childhood but usually the face and neck are quite severely affected as well as the limbs. Spontaneous resolution is much less likely than with viral warts; $(c)$ acrokeratosis verruciformis. This inherited keratoderma may look very like epidermodysplasia verruciformis. Lesions are often present at birth or early in childhood. Spontaneous improvement sufficient to be deemed a cure is most unlikely. No mention of a family history was made by the commissioners.

It does seem likely that Richard had viral warts which were unusually gross. Possibly they were present from early childhood rather than birth.

\section{Case history 6}

John de Burton was a boy who lived in Ludlow and managed to survive by begging and showing his defective tongue to passersby. Some of the 32 witnesses who attested to the miracle which cured John said that he had no vestige of a tongue, others that there was a little lump of flesh about the size of a thumb, beneath which was a hollow "as though the lump had a roo with a little tongue lower down." He could not speak but made noises variably described as babbling, howling like a dog, or lamenting. He had to put two fingers in his mouth to help himself swallow. A king's bailiff said that he had thought that the boy was a fraud and had had him whipped but that this had failed to make him speak.

When he was about 20 years old he was persuaded to go to the tomb of Thomas Cantilupe but returned without definite improvement. Examination at about that time by a "noteworthy matron of Ludlow" showed the lump about the size of a thumb with the end ("summitas") seeming to adhere to the roots of the teeth.

He went again to Hereford and slept and prayed by the tomb. Afterwards he said that Thomas had appeared to him, rubbed his throat, and pulled out his tongue to demonstrate that he had one. Witnesses reported that he was seen subsequently to have a long and beautiful tóngue, which he could stretch as far as his chin. No division or scar could be seen in the tongue and it was of a uniform colour. John was heard to speak, with the aid of his new tongue, fluently in English and Welsh. He himself did not appear before the commissioners and had been last seen, not long after the miracle, bearing a cross and setting off for the Holy Land with a priest. ${ }^{18}$

Comment-It is difficult to believe that John had "tongue tie" of sufficient degree to lead to apparent absence of the organ and with this condition he would probably have been able to swallow without inserting his fingers into

\section{Case history 5}

Richard d'Insula of the friars manor told the commissioners about the miracle which he had experienced 15 years earlier when he was 22 . He had had verrucas on his hands and feet all his life and had hardly dared to show his hands to anyone because of their inflamed appearance. He had had no social life as a consequence. He said that when he was student in Orleans he had once taken the coverings from his hands to write some notes and his colleagues had risen up from their benches to look at them; they had been so swollen that a pin could not be put between them. He had been treated with hot irons, sulphur, and the application of threads, in both England and France, without success. If one lesion did disappear another would take its place.

While in Orleans he had met a pilgrim from England and asked for news of the country. He was told that there was nothing of importance except that God was working miracles through a saint called Thomas de Cantilupe in Hereford. Richard prayed to Thomas and 24 hours later the verrucas began to disappear and all had gone by the third day except for one on the left index finger; this was later removed with a thread. ${ }^{17}$

Comment-This was another example of a miracle occurring at a distance from the shrine. Richard's description of the persistence of the lesion on his left hand adds verisimilitude to the story. Dr J R S Rendall (consultant dermatologist in Hereford) has given us three possible diagnoses: $(a)$ verruca vulgaris (viral warts). These may be multiple, very large, debilitating, and extremely persistent on the hands. Resolution may, of course, occur spontaneously. It would be most unusual

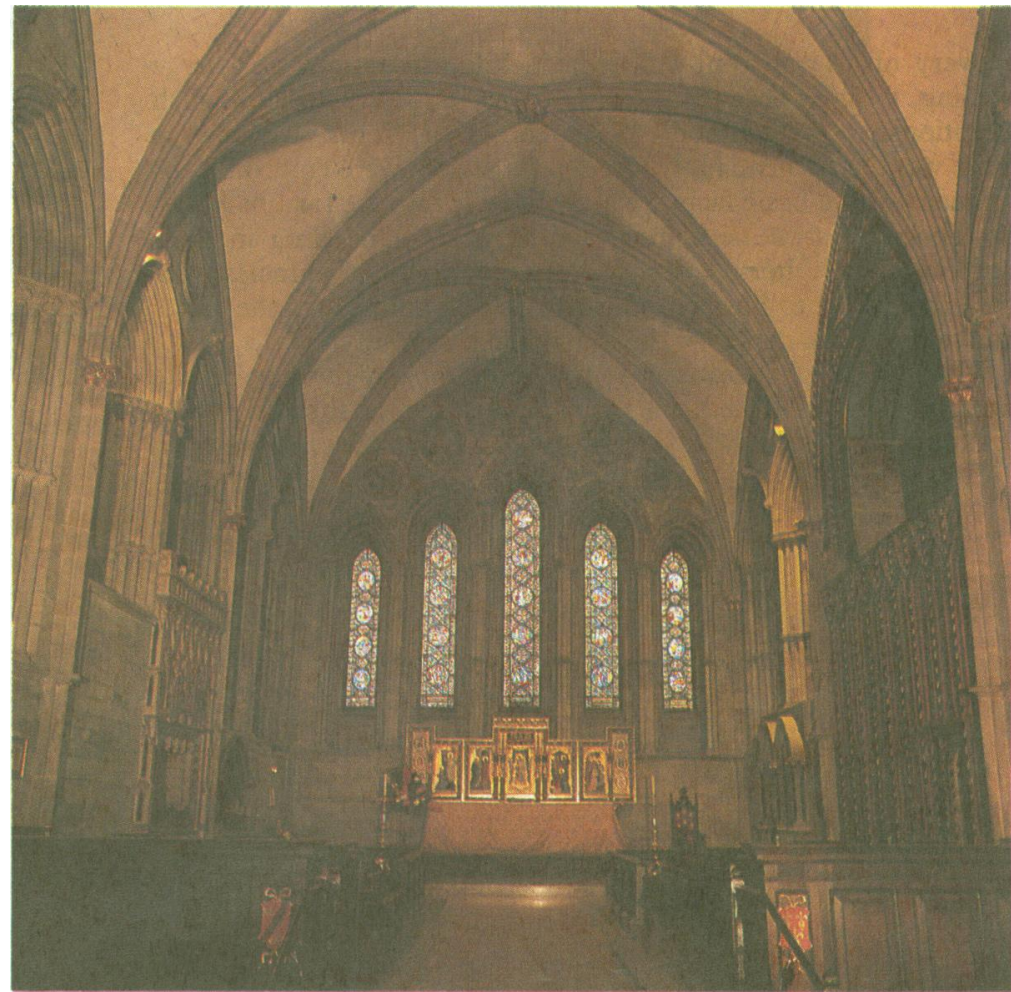

The Lady Chapel in Hereford Cathedral. 
his mouth. Perhaps he had some form of impaction of the tongue backwards with faulty muscular development.

\section{Conclusion}

Some of these stories are certainly "wonders" and might well appear so to modern laymen or even, if they are taken literally, to the medically informed. A patient suddenly ceasing to be maniacal,

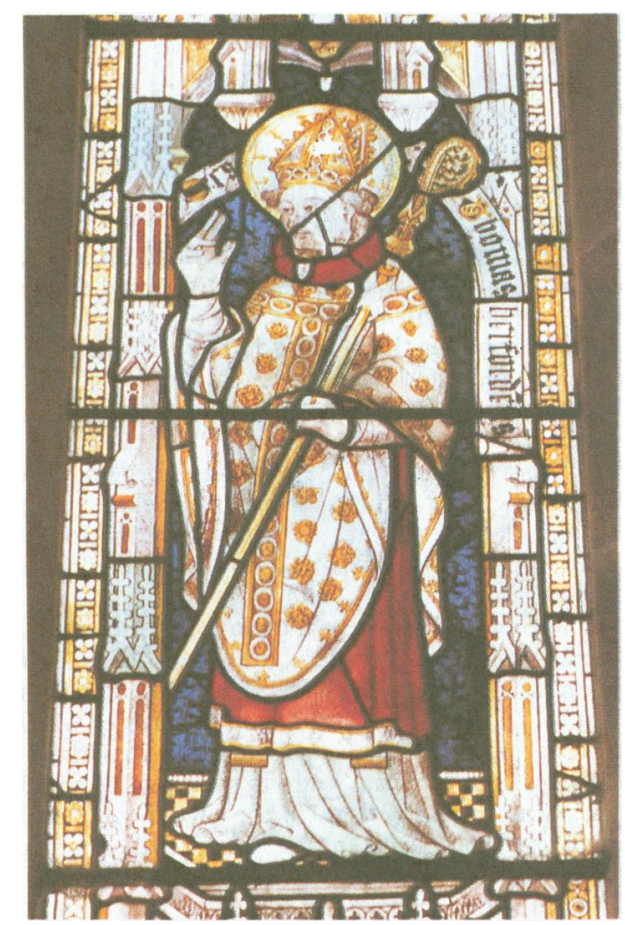

St Thomas. One of the four main lights of the east window in the parish church of St Mary, Ross on Wye, which came from the ruined chapel in a former palace of the Bishops of Hertford.

recovery of an apparently drowned child, resolution of a large swelling, vision where there had previously been blindness-such exceptions to the commonly observed run of events must always excite wonder in any age. No doubt the stories were embroidered, but many of the basic facts are acceptable for we are fortunate that the Thomas Cantilupe commissioners were demanding in their inquiries. The writers of some other descriptions of miracles were more concerned to illustrate the virtues and holiness of the saints than in providing details of the individual cases. ${ }^{19}$

What did the physicians and surgeons of the day think about the dramatic alternative medicine being practised at the shrines? We do not know but it is doubtful if it disturbed them in the same way that later practitioners have been upset by unorthodox practices, for their own work encompassed so much that was paramedical. The treatise The Rosa Anglica, written by John of Gaddesden (born about 1280 and the first careful and critical physician of distinction to have had his entire medical training in England ${ }^{20}$ ), is said to be a mixture of medical theories and teachings together with superstitious charms, folk remedies, and religious practices. ${ }^{19}$

Life in mediaeval England was for many people a struggle against poverty, miserable weather, and lack of food. Conditions became worse in the latter half of the thirteenth century as England became colder, the population increased, and a series of famines developed. The 1290 s were unusually wet and the crops rotted in the fields; famines and disease continued until the dramatic Black Death plague of 1347-51..$^{21}$ Perhaps the increasing misery in much of the population was a stimulant to their looking to the supernatural for help and reassurance and in the hope of finding panaceas and salvation from the ever present disasters.

We are grateful for helpful comments from medical colleagues. The first three photographs are by Mr Gordon Taylor and are reproduced by kind permission of the Dean and Chapter. The fourth is reproduced by kind permission of the Vicar of the Parish Church of St Mary, Ross on Wye.

\section{References}

1 Vat Cod Lat 4015, fo 146v et seq.

2 Daly PH. The process of canonization in the thirteenth and early fourteenth centuries. In: Jancey M, ed. St Thomas Cantilupe Bishop of Hereford. Hereford: The Friends of Hereford Cathedra Publications Committee, 1982:125-35.

3 Mayr-Harting $\mathbf{H}$. Functions of a twelfth century shrine: the miracles of St Frideswide. In: Mayr-Harting H, Moore RI, eds. Studies in medieval history, presented to R H C Davis. London: Mambledon Press, 1985:193-206.

4 Garvie AE. Miracle. Encyclopaedia Britannica. London: Encyclopaedia Britannica Ltd, 1961:15: 585-7.

5 Finucane RC. Miracles and pilgrims, popular beliefs in medieval England. London: Dent, 1977.

6 Walsh JJ. Medieval medicine. London: Black, 1920.

7 Ashe G. Miracles. London: Routledge, 1978.

8 Dawkins R. The blind watchmaker. Harlow: Longman, 1986.

9 Vat Cod Lat 4015, fo 18 et sq.

10 Vat Cod Lat 4015, fo 66 et seq.

11 Vat Cod Lat 4015, fo 183 et seg.

12 Marshall G. The shrine of St Thomas de Cantilupe in Hereford Cathedral. Transactions of the Woolhope Naturalists Field Club Herefordshire 1931:34-50.

13 Vat Cod Lat 4015, fo 211 et seg.

14 Finucane RC. The Cantilupe-Pecham controversy. In: Jancey M, ed. St Thomas Cantilupe Bishop of Hereford. Hereford: The Friends of Hereford Cathedral Publications Committee, 1982: 103-23.

15 Finucane RC. Cantilupe as thaumaturge; pilgrims and their "miracles." In: Jancey M, ed. $S$ Thomas Cantilupe of Hereford. Hereford: The Friends of Hereford Cathedral Publication Committee, 1982:137-44.

16 Bannister AT. The Hereford miracles. Transactions of the Woolhope Naturalists Field Club Herefordshire. Volume for 1902-4:377-83.

17 Vat Cod Lat 4015, fo 38 et seq.

18 Vat Cod Lat 4015, fo $103 \mathrm{v}$ et seq.

18 Vat Cod Lat 4015, fo 103v et seq.

20 Talbot CH. Medicine in medieval England. London: Oldbourne, 1967.

21 Gottfried RS. The Black Death. London: MacMillan, 1986.

Hereford

J H ROSS, MD, FRCP, retired physician

MERYL JANCEY, MA, Hereford Cathedral archivist

Correspondence to: Dr J H Ross, 22 Overbury Road, Hereford HR1 1JE. 